\title{
Contribution of Ectomycorrhizal Fungi to Cadmium Uptake of Poplars and Willows from a Heavily Polluted Soil
}

Journal Article

Author(s):

Sell, Joachim; Kayser, Achim; Schulin, R.; Brunner, Ivano

Publication date:

2005-12

Permanent link:

https://doi.org/10.3929/ethz-b-000030941

Rights / license:

In Copyright - Non-Commercial Use Permitted

Originally published in:

Plant and Soil 277(1-2), https://doi.org/10.1007/s11104-005-7084-5 


\title{
Contribution of ectomycorrhizal fungi to cadmium uptake of poplars and willows from a heavily polluted soil
}

\author{
Joachim Sell ${ }^{1,4}$, Achim Kayser ${ }^{2}$, Rainer Schulin ${ }^{2}$ \& Ivano Brunner ${ }^{3}$ \\ ${ }^{1}$ Chair of Natural and Social Science Interface (NSSI), Swiss Federal Institute of Technology Zurich, ETH \\ Zentrum HAD, CH-8092, Zurich, Switzerland. ${ }^{2}$ Institute of Terrestrial Ecology (ITÖ), Swiss Federal \\ Institute of Technology, Zurich, Grabenstrasse 3, CH-8952, Schlieren, Switzerland. ${ }^{3}$ Swiss Federal Institute \\ for Forest, Snow and Landscape Research (WSL), CH-8903, Birmensdorf, Switzerland. ${ }^{4}$ Corresponding \\ author*
}

Received 11 March 2005. Accepted in revised form 9 May 2005

Key words: cadmium, ectomycorrhiza, Paxillus involutus, phytoremediation, Populus canadensis, Salix viminalis

\begin{abstract}
Phytoextraction has been proposed in recent years as an environmentally and cost-efficient treatment technique for the remediation of heavy-metal contaminated sites. In particular, plants that are fast growing, metal accumulating, and economically interesting, such as sunflowers or trees, recently became more important in research on phytoextraction. Heavy metal uptake of trees can be strongly influenced by ectomycorrhizal fungi. We investigated the possibility of enhancing phytoextraction of Cd by willows (Salix viminalis) and poplars (Populus canadensis) in association with three well known ectomycorrhizal fungi (Hebeloma crustuliniforme, Paxillus involutus and Pisolithus tinctorius). A pot experiment was conducted using $\mathrm{Cd}$ polluted soil from a contaminated site. Four replicates of each combination of fungus and tree species, and controls without fungal inoculum, were set up. After a growth period of 11 weeks, yields and $\mathrm{Cd}$ concentrations in roots, stems, and leaves were measured. In addition, the total Cd uptake, the transfer to roots, and the translocation to stems and leaves were calculated. The association of $P$. canadensis with $P$. involutus led to a highly significant increase of $\mathrm{Cd}$ concentrations, in particular in the leaves, which contained $2.74 \pm 0.34 \mathrm{mg} \mathrm{Cd}$ per kg dry matter. Compared to the control this is an enhancement of nearly $100 \%$. The fungi also significantly enhanced the translocation from the roots to the leaves, leading to a concentration ratio (leaves/roots) of $0.32 \pm 0.06$ compared to $0.20 \pm 0.02$ of the control plants. Additionally, $P$. involutus significantly enhanced the total Cd extraction by $P$. canadensis. Similar effects were not observed by other fungi or in association with $S$. viminalis.
\end{abstract}

\section{Introduction}

Apart from 'hot spots' of very high concentration of pollutants confined in rather small areas, there also exist large pollution areas with relatively low heavy metal concentration levels (ETCS, 1998;

\footnotetext{
* FAX No: +41-1-632-10-29.

E-mail: joachim.sell@env.ethz.ch
}

Vogel et al., 1989). These may originate from atmospheric deposition of industrial and traffic emissions or pesticides, mineral fertilizers, and sewage sludges by agricultural application. While there is usually little danger of immediate toxicity effects in these cases, the problem is the large mass of metals introduced into the environment that may, in the long term, accumulate and poison food chains and water resources (Hämmann 
and Gupta, 1997). Prevention of such accumulation must be the primary strategy of soil protection, but additional measures should be envisaged to reduce existing concentration levels in soils, if possible.

In recent years, phytoextraction has been proposed as a cost-efficient and sustainable technology for this purpose, particularly for soils that are intended to be kept under use for plant production (McGrath et al., 2001). In contrast to such techniques as soil washing, phytoextraction is a gentle soil treatment, as it conserves physical soil structure and restores ecological soil quality (Saxena et al., 1999, Schulin et al., 1997). Its major disadvantage is the comparatively long time span required. This may be of a lesser problem on sites on which land-use can be combined with the growth of metal-accumulating trees, e.g. the stabilization of slopes by willows, the production of woods or fuel by poplar cultivation or mixed agroforestry systems (McIntyre, 2003; Rockwood et al., 2004). The industrial use of plants, however, depends on the metal contents and their location in plants. It would be favorable if the plant parts used (e.g. stems) showed low metal contents. For the disposal of the contaminated not-usable plant material several measures have been proposed, including incineration (Prasad and de Oliveira Freitas, 2003).

In particular in soils with near-neutral or basic $\mathrm{pH}$, low phytoavailability of metals has been considered as a major limitation for phytoextraction of metal pollutants (Kayser et al., 2000). The uptake of rather mobile metals such as zinc and cadmium can be significantly increased by solubilization of the metals through acidification of the soil (Kayser et al., 2001) or reactions with ligands forming mobile complexes (Meers et al., 2004; Wenger et al., 2002). These approaches rely on an enhanced transport of dissolved metals to the roots by diffusion.

Among the biological factors governing metal extraction, the role of microorganisms, in particular fungi, is important. The various influences of ectomycorrhizal fungi on the uptake of heavy metals in plants is widely documented in literature, but so far not specifically with respect to a possible technical application in phytoremediation. Literature reports that when there is low metal concentration in the soil the fungi enhance the uptake in plants (Colpaert and Van Assche, 1987; Smith and Read, 1997), whereas at high metal concentrations the fungi provide a filter function that leads to improved metal tolerance by plants (Bücking and Heyser, 1994; Jentschke and Godbold, 2000; Jones and Hutchinson, 1988; Leyval et al., 1997). But also enhanced uptake (Colpaert and Van Assche, 1992) or increased toxicity of heavy metals (Godbold, 1994) due to the presence of fungi are mentioned, even though these effects have not been observed in many studies.

The main effects, enhancement of metal uptake or filter function, respectively, may change under different growing conditions with different plant and fungal species and the metals considered (Hartley et al., 1997). These effects cannot simply be generalized on any plant-fungus association in any experimental set-up (Godbold et al., 1998; Jentschke and Godbold, 2000). This large variability of ectomycorrhizal effects on heavy metal uptake by plants can be seen as an opportunity for successful screening of suitable plant-fungus formations in technical applications such as phytoremediation. In addition, the ectomycorrhizal fungi preferable are located in the upper soil layers where the highest concentrations of heavy metals are found. Berthelsen et al. (1995) showed that in the soil of a coniferous forest of southern Norway, contaminated with $\mathrm{Cd}, \mathrm{Cu}$, and $\mathrm{Zn}$, most of the heavy metals were accumulated in the mycelia of mycorrhizal fungi.

This survey investigated the contribution of three well known ectomycorrhizal fungi (Hebeloma crustuliniforme, Paxillus involutus, and Pisolithus tinctorius) to the $\mathrm{Cd}$ uptake of a proofed $\mathrm{Cd}$ accumulator (Salix viminalis; Greger (1999)) and a fast growing common tree species (Populus canadensis). In order to provide conditions with relevance for phytoextraction a pot experiment was conducted using soil from a contaminated site. The results present $\mathrm{Cd}$ concentrations in different plant parts, the transfer of $\mathrm{Cd}$ to the plant roots, and the translocation to stems and leaves. The impacts of fungi on Cd uptake are analyzed by ANOVA. We discuss the plant-fungus associations with respect to potential applications in phytoextraction of heavy metals from contaminated soils. 
Materials and methods

\section{Soil}

The soil used in the pot experiment originated from Dornach (Canton of Solothurn), which is the main case study of Swiss research projects concerning phytoremediation (Hesske et al., 1998). The site had been contaminated during decades of air pollution from a metal smelter. The soil was classified as calcaric regosol. The main soil parameters are characterized as follows: clay $32 \%$, silt $50 \%$, sand $18 \% ; \mathrm{C}_{\text {org }} 4.4 \%, \mathrm{CaCO}_{3} 13.5 \%$; $\mathrm{CEC}_{\text {pot }} 26 \mathrm{meq} \cdot 100 \mathrm{~g}^{-1} ; \mathrm{pH}\left(\mathrm{CaCl}_{2}\right) 7.4$ (Keller et al., 2003). Thus, this calcareous soil is not favorable for phytoremediation, since heavy metals are strongly adsorbed to the solid phase (Meers et al., 2004). The $\mathrm{Cd}$ total concentration (2 M $\mathrm{HNO}_{3}$ extraction; (FAC, 1989) is $1.91 \mathrm{mg} \mathrm{kg}^{-1}$, the soluble concentration $\left(0.1 \mathrm{M} \mathrm{NaNO}_{3}\right.$ extraction; (FAC, 1989) is $0.003 \mathrm{mg} \mathrm{kg}^{-1}$ soil. In addition, the soil is contaminated with $\mathrm{Zn}$ (soluble concentration $0.075 \mathrm{mg} \mathrm{kg}^{-1}$ ) and $\mathrm{Cu}$ (soluble concentration $0.79 \mathrm{mg} \mathrm{kg}^{-1}$ ). Previously to the experiment the soil was homogenized and sterilized by means of gamma-radiation with ${ }^{60} \mathrm{Co}$.

\section{Fungi}

The mycelia of three different fungi species, Hebeloma crustuliniforme (Bull.:St. Amans) Quél. (WSL \#6.2), Paxillus involutus (Batsch:Fr.) Fr. (WSL \#37.7), and Pisolithus tinctorius (Pers.) Desv. (WSL \#10.1), were grown on nutrient agar in Petri dishes, cut with a sterilized scalpel into square pieces of $5 \times 5 \mathrm{~mm}$, and added in autoclaved $3 \mathrm{~L}$ polycarbonate flasks (Le Lion flask) containing $2 \mathrm{~L}$ vermiculite:peat mixture $(9: 1 ; \mathrm{v}: \mathrm{v})$, moistened with $450 \mathrm{~mL}$ MMN nutrient solution (Marx and Bryan, 1975). After an incubation time of three months at $20{ }^{\circ} \mathrm{C}$, demineralized water was flushed through the substrate in order to wash out the remaining nutrient solutions.

The fungal strains used were not specifically isolated from polluted sites; $H$. crustuliniforme was isolated from fruiting bodies from an unpolluted Picea-forest stand, and P. involutus was isolated from fruiting bodies from an unpolluted Salix- and Betula-stand. Both stands were located in Switzerland. P. tinctorius was orginally obtained from Athens, Georgia, USA.

\section{Plants}

In winter cuttings of Populus canadensis (Populus $\times$ euramericana (Dode) Guinier cv. Dorskramp, proceeding from the Swiss Federal Institute for Forest, Snow and Landscape Research) and of Salix viminalis L. (clone number 78198, from the Department of Botany, University of Stockholm) were cut in pieces of $20 \mathrm{~cm}$ length, sealed at the ends with wax, and stored at low temperature until the start of the pot experiment.

\section{Pot experiment}

In spring the three different fungi, inclusively the vermiculite, were inoculated in $1.5 \mathrm{~L}$ pots of polyethylene filled with $1400 \mathrm{~g}$ of air dried, homogenized, and sterile contaminated soil of Dornach. The fungal inoculums were posed in the middle of the pot using approximately $200 \mathrm{~mL}$ of substrate. Each treatment was replicated four times with four control pots without any fungal inoculum. Each replicate grew in its own pot. The cuttings were planted directly in the middle of the inoculate and then covered with inoculate and soil.

Plants were grown in a greenhouse with temperatures set between 10 and $25^{\circ} \mathrm{C}$, with air humidity at least $70 \%$. Pots were irrigated from polyethylene containers by means of wicks made of glass fiber. No fertilizers were applied.

After 11 weeks the plants were harvested and separated into roots, stems, and leaves. Roots were washed carefully with flowing demineralized water. The presence of ectomycorrhizal fungal hyphae or of ectomycorrhizas was determined using a dissecting microscope.

The material was dried at $60{ }^{\circ} \mathrm{C}$, cut in a centrifugal mill (Retsch ZM-1) and digested (about $100 \mathrm{mg}$ material) in a microwave oven (MLSETHOS) using $5 \mathrm{~mL}$ of an agent containing $\mathrm{HNO}_{3}(65 \%), \mathrm{H}_{2} \mathrm{O}_{2}(30 \%)$ and $\mathrm{H}_{2} \mathrm{O}$ in the ratio $2.5: 1: 1$. In order to provide a quality control, a standard material (ray grass, CRM 281) was integrated in each series.

The $\mathrm{Cd}$ content of the dissolved plant material was determined by means of atomic absorption spectrometry (Varian SpectrAA 300, 6TA96). Each sample was measured three times, repeating the measurements if the standard deviation exceeded $10 \%$. 
Differences between treatments were assessed by one- or two-factorial analysis of variance (ANOVA). Least significant differences were calculated at $P \leq 0.05$ using Fisher's PLSD test. All tests were conducted using StatView 4.5.

\section{Results}

\section{Biomass and Cd concentrations}

Fungal hyphae were found along plant roots in all inoculated pots. However, formation of mycorrhizas containing a typical fungal mantel were only observed in $P$. canadensis inoculated with $P$. involutus in about $5 \%$ of all short roots. In the controls without inoculums no fungal hyphae were found.

The contribution of the three different fungi to the biomass and the $\mathrm{Cd}$ concentrations in the plants are shown in Table 1 for $P$. canadensis and Table 2 for $S$. viminalis, respectively. Obviously, the biomass production of $P$. canadensis was higher than that of $S$. viminalis, particularly in the leaves. Neither of the two plant species were strongly influenced on their biomass production by the different fungi, even though in both cases the controls tended to show the lowest biomass (not significant), and $P$. canadensis tended to show (not significant) enhanced biomass in treatments with $P$. involutus and $H$. crustuliniforme.

Both plant species showed comparable $\mathrm{Cd}$ concentrations in the roots and stems, whereas concentrations in the leaves of $S$. viminalis were much higher than in $P$. canadensis (Tables 1 and 2 ).

Paxillus involutus significantly enhanced $\mathrm{Cd}$ concentrations in the above ground material of $P$. canadensis, compared to the controls and to the treatment with $H$. crustuliniforme (Table 1). The treatment with $P$. tinctorius also led to significantly higher above ground concentrations, but this effect was less pronounced than observed in $P$. involutus. Regarding the different plant parts, $\mathrm{Cd}$ concentrations were highest in the roots. The results in Table 2 show that $S$. viminalis contained similar or higher Cd concentrations in the leaves than in the roots. Compared to the controls, $P$. involutus did not significantly affect $\mathrm{Cd}$ concentrations. Treatments with $H$. crustuliniforme and $P$. tinctorius showed reduced $\mathrm{Cd}$ concentrations in the leaves or roots, respectively, and higher concentrations in the stems.

\section{Cadmium uptake and root to shoot translocation}

Pisolithus tinctorius and $P$. involutus led to a higher transfer of $\mathrm{Cd}$ from the soil into the roots of $P$. canadensis (Table 3), when compared to the effect of $H$. crustuliniforme. Regarding the above ground material, $P$. involutus supported the translocation of $\mathrm{Cd}$ to the leaves when compared to the controls. In the case of $S$. viminalis, the treatment with $P$. tinctorius showed a significantly reduced transfer to the roots. No other significant effects were observed.

Table 1. Biomass and $\mathrm{Cd}$ concentrations of Populus canadensis inoculated with three different mycorrhizal fungi or non-inoculated controls

\begin{tabular}{|c|c|c|c|}
\hline & Roots & Stem & Leaves \\
\hline & \multicolumn{3}{|l|}{ Biomass (g) } \\
\hline Control & $0.52 \pm 0.10 \mathrm{a}$ & $2.70 \pm 0.39 \mathrm{~b}$ & $6.01 \pm 0.95 \mathrm{a}$ \\
\hline H. crustuliniforme & $0.66 \pm 0.21 \mathrm{a}$ & $4.05 \pm 0.44 \mathrm{a}$ & $7.52 \pm 0.54 \mathrm{a}$ \\
\hline P. involutus & $0.71 \pm 0.14 \mathrm{a}$ & $4.28 \pm 0.52 \mathrm{a}$ & $7.26 \pm 0.53 \mathrm{a}$ \\
\hline \multirow[t]{2}{*}{ P. tinctorius } & $0.43 \pm 0.09 \mathrm{a}$ & $3.43 \pm 0.37 \mathrm{ab}$ & $6.35 \pm 0.45 \mathrm{a}$ \\
\hline & \multicolumn{3}{|c|}{ Cd concentration ( $\mathrm{mg} \mathrm{kg}^{-1}$ dry matter) } \\
\hline Control & $7.97 \pm 0.13 \mathrm{ab}$ & $0.69 \pm 0.09 \mathrm{~b}$ & $1.51 \pm 0.16 \mathrm{c}$ \\
\hline H. crustuliniforme & $6.63 \pm 0.35 \mathrm{~b}$ & $0.77 \pm 0.04 \mathrm{~b}$ & $1.96 \pm 0.11 \mathrm{bc}$ \\
\hline P. involutus & $8.66 \pm 0.44 \mathrm{a}$ & $1.02 \pm 0.06 \mathrm{a}$ & $2.74 \pm 0.34 \mathrm{a}$ \\
\hline P. tinctorius & $9.61 \pm 1.04 \mathrm{a}$ & $0.85 \pm 0.07 \mathrm{ab}$ & $2.20 \pm 0.07 \mathrm{ab}$ \\
\hline
\end{tabular}

Values are means and standard errors of four replicates. Values within columns followed by different letters are significantly different at $P \leq 0.05$. 
Table 2. Biomass and $\mathrm{Cd}$ concentrations of Salix viminalis inoculated with three different mycorrhizal fungi or non-inoculated controls

\begin{tabular}{|c|c|c|c|}
\hline & Roots & Stem & Leaves \\
\hline & \multicolumn{3}{|l|}{ Biomass (g) } \\
\hline Control & $0.40 \pm 0.18 \mathrm{a}$ & $2.73 \pm 0.92 \mathrm{a}$ & $2.25 \pm 0-65 \mathrm{a}$ \\
\hline H. crustuliniforme & $0.61 \pm 0.33 \mathrm{a}$ & $3.33 \pm 1.11 \mathrm{a}$ & $2.66 \pm 0.56 \mathrm{a}$ \\
\hline P. involutus & $0.55 \pm 0.18 \mathrm{a}$ & $3.95 \pm 0.75 \mathrm{a}$ & $2.98 \pm 0.50 \mathrm{a}$ \\
\hline \multirow[t]{2}{*}{ P. tinctorius } & $0.65 \pm 0.10 \mathrm{a}$ & $4.12 \pm 0.43 \mathrm{a}$ & $3.21 \pm 0.30 \mathrm{a}$ \\
\hline & \multicolumn{3}{|c|}{$\mathrm{Cd}$ concentration ( $\mathrm{mg} \mathrm{kg}^{-1}$ dry matter) } \\
\hline Control & $7.42 \pm 0.30 \mathrm{a}$ & $1.54 \pm 0.18 \mathrm{~b}$ & $7.75 \pm 0.59 \mathrm{a}$ \\
\hline H. crustuliniforme & $6.00 \pm 0.21 \mathrm{ab}$ & $2.38 \pm 0.22 \mathrm{a}$ & $6.30 \pm 0.44 \mathrm{~b}$ \\
\hline P. involutus & $7.36 \pm 0.49 \mathrm{a}$ & $1.97 \pm 0.03 \mathrm{ab}$ & $7.77 \pm 0.41 \mathrm{a}$ \\
\hline P. tinctorius & $4.50 \pm 1.00 \mathrm{~b}$ & $2.06 \pm 0.04 \mathrm{a}$ & $6.83 \pm 0.24 \mathrm{ab}$ \\
\hline
\end{tabular}

Values are means and standard errors of four replicates. Values within columns followed by different letters are significantly different at $P \leq 0.05$.

Table 3. Transfer (soil to root) and translocation (root to stems or leaves) coefficients of $\mathrm{Cd}$ for P. canadensis and S. viminalis inoculated with three different mycorrhizal fungi or non-inoculated controls

\begin{tabular}{llll}
\hline & Transfer (roots/soil) & Translocation I (stem/root) & Translocation II (leaves/roots) \\
\hline P. canadensis & & & \\
Control & $4.17 \pm 0.07 \mathrm{ab}$ & $0.10 \pm 0.00 \mathrm{a}$ & $0.20 \pm 0.02 \mathrm{~b}$ \\
H. crustuliniforme & $3.47 \pm 0.18 \mathrm{~b}$ & $0.12 \pm 0.01 \mathrm{a}$ & $0.30 \pm 0.01 \mathrm{ab}$ \\
$P$. involutus & $4.54 \pm 0.23 \mathrm{a}$ & $0.12 \pm 0.01 \mathrm{a}$ & $0.32 \pm 0.06 \mathrm{a}$ \\
$P$. tinctorius & $5.03 \pm 0.55 \mathrm{a}$ & $0.09 \pm 0.01 \mathrm{a}$ & $0.24 \pm 0.03 \mathrm{ab}$ \\
S. viminalis & & & \\
Control & $3.89 \pm 0.16 \mathrm{a}$ & $0.18 \pm 0.02 \mathrm{a}$ & $1.13 \pm 0.04 \mathrm{a}$ \\
H. crustuliniforme & $3.14 \pm 0.11 \mathrm{ab}$ & $0.40 \pm 0.04 \mathrm{a}$ & $1.06 \pm 0.09 \mathrm{a}$ \\
$P$. involutus & $3.85 \pm 0.26 \mathrm{a}$ & $0.27 \pm 0.02 \mathrm{a}$ & $1.08 \pm 0.14 \mathrm{a}$ \\
$P$. tinctorius & $2.35 \pm 0.52 \mathrm{~b}$ & $0.60 \pm 0.21 \mathrm{a}$ & $1.94 \pm 0.64 \mathrm{a}$ \\
\hline
\end{tabular}

Values are means and standard errors of four replicates. Values within columns followed by different letters are significantly different at $P \leq 0.05$.

\section{Total cadmium uptake}

In general, the data revealed that the Cd uptake of $P$. canadensis was comparable to that of $S$. viminalis (Figure 1). In both plants most $\mathrm{Cd}$ was accumulated in the leaves, compared to stems and roots.

In the case of $P$. canadensis, $P$. involutus significantly enhanced total $\mathrm{Cd}$ accumulation in the leaves compared to all other treatments, being more than $100 \%$ higher than in the control treatments. In addition, the uptake in the stems was significantly increased. The presence of the two other fungi also led to significantly enhanced accumulation in the leaves.

In contrast, the fungi seemed to have little influence on the total $\mathrm{Cd}$ removal of $S$. viminalis.
The effects observed were not statistically significant.

\section{Discussion}

\section{Fungal and plant growth}

Even though fungal hyphae were present in all root samples of both plant species, mycorrhizal mantle could only be observed in the association of $P$. canadensis with $P$. involutus. However, both plant species are known from the literature to form ectomycorrhiza. Püttsepp et al. (2004), studying a $S$. viminalis plantation, found ectomycorrhizas of several genera and species, including one species of Hebeloma. Jones et al. (1990) 

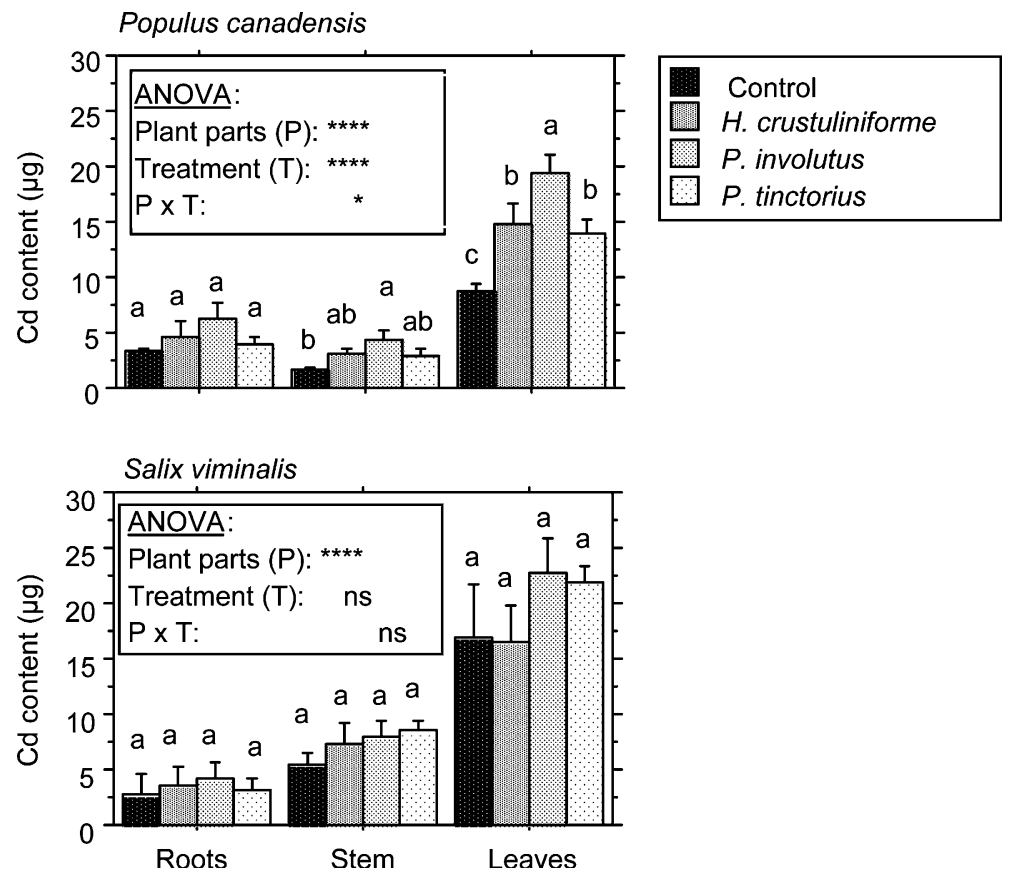

Figure 1. Total Cd content of P. canadensis and S. viminalis showing the different treatments. Values are means and standard errors of four individual plants. Bars with different letters are significantly different at $P \leq 0.05$. Probability level for ANOVA: ns $=$ not significant; $*=$ significant at $P \leq 0.05 ; * * *=$ significant at $P \leq 0.0001$.

combined S. viminalis plants with Laccaria proxima and Telephora terrestris and observed typical features of ectomycorrhiza. A study conducted by Heslin and Douglas (1986) found typical mycorrhiza in combination with the three fungi used in our study and a poplar hybrid. In pot and field experiments Loree et al. (1989) observed mycorrhizal structures with $S$. viminalis and $H$. crustuliniforme and $P$. involutus, respectively.

One reason for the poor formation of mycorrhizas is very likely the unfavorable soil conditions, e.g. the high $\mathrm{pH}$. However, it remains unclear which soil parameters hampered the mycorrhiza formation. Since the soil was under agricultural use it is also possible that high nutrient levels impaired the mycorrhiza formation. However, nutrient levels were not examined in this survey since focus was laid on parameters affecting the $\mathrm{Cd}$ availability. It could also have been that the presence of high heavy metal concentrations, or the combination of the three metals, prevented the fungi from rapidly growing and forming the mycorrhiza within the time frame of the experiment. However, an in vitro experiment, described in Tam (1995), showed that e.g. P. tinctorius showed high resistance to a variety of heavy metals (including $\mathrm{Cd}, \mathrm{Cu}$ and $\mathrm{Zn})$ when compared to other fungi.

Besides of a qualitative check on the plants' aspect, the biomass was used as an indicator for heavy metal tolerance or vitality of the plants (Godbold et al., 1998; Turner, 1994). The fact that none of the treatments led to significantly lower biomass, combined with the absence of typical insufficiency symptoms in the aspect of the plants, is interpreted as an indication that in no case the heavy metal concentrations endangered the vitality of the plants in the time frame of this experiment. The fact that the poplars produced even more biomass than the fast growing willows, particularly in the leaves, is important for the total Cd uptake, and consequently, for successful use as phytoremediation plant.

\section{Contribution of mycorrhiza}

The association of $P$. canadensis with $P$. involutus clearly showed that the presence of fungi and mycorrhization enhanced the total Cd uptake by the plants. In literature it is well documented that mycorrhiza can support the heavy metal uptake of plants in the case of low soil concentrations 
(Colpaert and Van Assche, 1987; Godbold et al., 1998). However, an enhancement of heavy metal uptake in plants, induced by mycorrhiza, in the case of high contaminations is not often found. In an experiment from Colpaert and Van Assche (1992) some strains of ectomycorrhizal fungi caused decreased $\mathrm{Zn}$ concentrations in the needles of Pinus sylvestris, whereas the fungus Telephora terrestris enhanced the contents. As discussed later, the augmentation of $\mathrm{Cd}$ concentration in the present study went hand in hand with an increased translocation, which is of main importance for phytoextraction. Thus, the data indeed suggests that an appropriate application of ectomycorrhizal fungi can significantly support the capacity of Cd extraction in the case of $P$. canadensis.

As shown, the significant enhancements of $\mathrm{Cd}$ uptake are not necessarily dependent on the formation of mycorrhizas, but are due to the simple presence of fungal mycelia in the pots. This was observed in the case of $\mathrm{Cd}$ concentration in poplar leaves with the treatment $P$. tinctorius compared to the control (see Table 1). It has been demonstrated that mycorrhizal fungal hyphae and plant roots can interact through phytohormones such as auxins or IAA (Beyrle, 1995; Salzer and Hager, 1993). For example, Allen (1991) described reduced metal tolerance of non-mycorrhizal plants in the presence of mycorrhizal fungi, showing that influences on metal physiology may occur without the formation of mycorrhiza. In addition, fungi are known to release organic acids that enhance availability of $\mathrm{Cd}$ in the rhizosphere and thus support the uptake (Leyval et al., 1993; Turnau et al., 1995).

The above mentioned increase of Cd uptake in the association of poplars with $P$. involutus could be the result of fungal exudates such as organic acids or siderophores (Leyval et al., 1997). Such an effect of the fungi might be more clearly observed in a natural soil with various metal binding sites, as was used in the present study. This is unlike most laboratory experiments where usually soluble metal salts are combined with substrates such as sand. In particular, $P$. involutus is able to dissolve minerals by exuding oxalic acid, particularly in calcareous soils (Lapeyrie et al., 1987, 1991).

Baker and Walker (1990) suggested a classification system of plant strategies for heavy metal pollutions, distinguishing between excluder, accu- mulator, and indicator strategies. The observed influence of $P$. involutus on the $\mathrm{Cd}$ uptake of $P$. canadensis is interpreted in the sense of the accumulator strategy, since high $\mathrm{Cd}$ concentrations and high translocation rates are combined with high (or at least not low) yields. In an analogy for proposed combinations of heavy metal tolerant fungi with an excluder plant (Allen, 1991; Wilkinson and Dickinson, 1995) we suggest that an association of a fungus that enhances the metal uptake with a heavy metal accumulator plant can also be a potential strategy to cope with heavy metal pollutions. Yet it is not clear if this can lead to mutual advantages for the symbionts in longer time frames, e.g. indicated by increased biomass. In this context it should be mentioned that in some cases fungi were found to enhance toxicity of heavy metals for plants (Godbold, 1994). These accumulator associations are of major interest for phytoremediation and should be further investigated in this context.

Similarly, the high translocation factors of $S$. viminalis with $P$. tinctorius are correlated with low root concentrations and high yields that are typical symptoms of the excluder strategy (Baker and Walker, 1990). In this case a protective function (filter function) of the fungi is supposed, as reported in several studies (Bücking and Heyser, 1994; Colpaert and Van Assche, 1992; Jones and Hutchinson, 1988; Tam, 1995) in the case of high heavy metal pollutions.

\section{Conclusions for phytoremediation}

In order to combine the $\mathrm{Cd}$ concentrations in plant tissue with the biomass the total Cd uptake was calculated for plant parts and compared between the different treatments and plants. This parameter is crucial for successful use of the plants as phytoextractors. Generally, P. canadensis shows a relatively high total $\mathrm{Cd}$ uptake, which makes it a potential alternative to other suggested accumulators such as $S$. viminalis or Nicotiana tabacum (Hammer et al., 2003; Kayser et al., 2000) for the phytoremediation of Cd contaminated sites.

Generally, S. viminalis had higher Cd concentrations in leaves and stems than $P$. canadensis, which is in line with the literature (e.g. Robinson et al., 2000). Robinson et al. (2000) conducted pot experiments using several poplar and willow 
varieties exposed to soil contaminated with differing levels of $\mathrm{Cd}$. At relatively low soil concentrations $\left(0.6-5.6 \mathrm{mg} \mathrm{kg}^{-1}\right.$ dry matter) the plant tissues showed concentrations in the range found in this study. However, in a field trial on a heavily polluted soil, Robinson et al. (2000) report Cd concentrations in the leaves of a poplar variety of up to $200 \mathrm{mg} \mathrm{kg}^{-1}$. That is almost ten times more than discovered in this study, and gives a hint for the potential of at least some fast growing poplar varieties for phytoextraction.

The Cd concentration ( $\mathrm{mg} \mathrm{kg}^{-1}$ dry matter) in all parts of both plants, except the stems of $P$. canadensis, showed higher concentrations than the soil total $\mathrm{Cd}$ concentration. However, the maximum total $\mathrm{Cd}$ content in plants (around $0.003 \mathrm{mg}$ in the case of $P$. canadensis in association with $P$. involutus, and $0.0035 \mathrm{mg}$ in the case of $S$. viminalis with the same fungus) corresponds only to approximately $1 \%$ of total $\mathrm{Cd}$ content in the soil per pot. Accordingly, a remediation of this soil would require a great deal of time. As mentioned before, the soil used here is not favorable for phytoremediation due to its high $\mathrm{pH}$ and CEC (see materials and methods). However, the proper scale to discuss plants' performance in phytoremediation is the long term field trial. Here we refer to a survey describing a five year field trial using $S$. viminalis on heavy metal contaminated sites (Hammer et al., 2003).

Even though the filter function of fungi, in the case of high contaminated soils, dominates the literature, this study shows that a $100 \%$ enhancement of the total $\mathrm{Cd}$ uptake is possible. This makes the respective association an interesting option for the improvement of the efficacy of phytoremediation. The technical application of fungi in phytoremediation can lean on the experiences gained in inoculation programs concerning reforestation activities in case of industrial tree species (Haselwandter and Bowen, 1996; Saxena et al., 1999; Smith and Read, 1997).

However, it needs to be investigated whether or not the effects found can also be observed in field experiments. Jones and Hutchinson (1988) suggest that the heavy metal tolerance of fungi found in in-vitro experiments cannot be transferred to field conditions in any case. Wallenda and Kottke (1998) provided a review about physiological adaptations of ectomycorrhiza with regard to nitrogen supply suggesting mycorrhizal adaptation to site-specific conditions. Wilkinson and Dickinson (1995) mentioned the capacity of adaptation and the genetic variation found in fungi, emphasizing that genotypes of tolerant fungi are selected by their tolerance at heavy metal contaminated sites. This variation and adaptation capacity can be seen as an opportunity to successfully combine tolerant fungi with tolerant plant varieties, leading to associations in the sense of the accumulator strategy. These associations, as found in the case of $P$. canadensis with $P$. involutus, should be taken into account in attempts to optimize phytoremediation in forthcoming pot trials and on the field scale.

\section{Acknowledgements}

We are grateful to the Swiss Federal Institute of Technology and the Swiss National Science Foundation for the financial support of this project. We thank FA Wädenswil for sterilizing the soil, and the Dept. of Botany at the University of Stockholm for the cuttings of $S$. viminalis.

\section{References}

Allen M F 1991 The Ecology of Mycorrhizae. Cambrige University Press. 196 p.

Baker A J M and Walker P L 1990 Ecophysiology of metal uptake by tolerant plants. In Heavy Metal Tolerance in Plants: Evolutionary Aspects. Ed. A J Shaw pp. 155-177. CRC Press, Boca Raton.

Berthelsen B, Olsen R A and Steinnes E 1995 Ectomycorrhizal heavy metal accumulation as a contributing factor to heavy metal levels in organic surface soils. Sci. Tot. Environ. 170, 141-149.

Beyrle H 1995 The role of phytohormones in the function and biology of mycorrhizas. In Mycorrhiza (Structure, Function, Molecular Biology and Biotechnology). Eds. A Varma. and B Hock. pp. 365-390. Springer, Berlin.

Bücking H and Heyser W 1994 The effect of ectomycorrhizal fungi on $\mathrm{Zn}$ uptake and distribution in seedlings of Pinus sylvestris L. Plant Soil. 167, 203-212.

Colpaert J V and Van Assche J A 1987 Heavy metal tolerance in some ectomycorrhizal fungi. Funct. Ecol. 1, 415-421.

Colpaert J V and Van Assche J A 1992 Zink toxicity in ectomycorrhizal Pinus sylvestris. Plant Soil 143, 201-211.

ETCS 1998 Topic Report - Contaminated sites. pp 142. European Environmental Agency.

FAC 1989 Methoden für die Bodenuntersuchungen. Schriftenreihe der FAC 5. Eidgenössische Forschungsanstalt für Agrikulturchemie und Umwelthygiene, Liebefeld, Bern 267 pp. 
Godbold D L 1994 Aluminum and heavy metal stress: From the rhizosphere to the whole plant. In Effects of Acid Rain on Forest Processes. Eds. D L Godbold and A Hüttermann. pp. 231-264. Wiley-Liss, New York.

Godbold D L, Jentschke G, Winter S and Marschner P 1998 Ectomycorrhizas and amelioration of metal stress in forest trees. Chemosphere 36, 757-762.

Greger M 1999 Metal availability and bioconcentration in plants. In Heavy Metal Stress in Plants. Eds. M N V Prasad and J Hagemeyer. pp. 1-27. Springer, Berlin.

Hämmann M and Gupta S K 1997 Herleitung von Prüf- und Sanierungswerten für anorganische Schadstoffe im Boden. Umweltmaterialien 83, BUWAL, Bern 100 pp.

Hammer D, Kayser A and Keller C 2003 Phytoextraction of Cd and $\mathrm{Zn}$ with Salix viminalis in field trials. Soil Use Manage. 19, 187-192.

Hartley J, Cairney J W G and Meharg A A 1997 Do ectomycorrhizal fungi exhibit adaptive tolerance to potentially toxic metals in the environment? Plant Soil 189, 303-319.

Haselwandter K and Bowen G D 1996 Mycorrhizal relations in trees for agroforestry and land rehabilitation. Forest Ecol. Manag. 81, 1-17.

Heslin M C and Douglas G C 1986 Synthesis of poplar mycorrhizas. T. Brit. Mycol. Sol. 86, 117-122.

Hesske S, Schärli M, Tietje O and Scholz R W 1998 Zum Umgang mit Schwermetallen im Boden: Falldossier Dornach. Pabst Science Publisher, Lengerich, Germany 145 pp.

Jentschke G and Godbold D L 2000 Metal toxicity and ectomycorrhizas. Physiol. Plantarum 109, 107-116.

Jones M D, Durall D M and Tinker P B 1990 Phosphorus relations and production of extramatrical hyphae by two types of willow ectomycorrhizas at different soil phosphorus levels. New Phytol. 115, 259-267.

Jones M D and Hutchinson T C 1988 Nickel toxicity in mycorrhizal birch seedlings infected with Lactaria rufus or Scleroderma flavidum. New. Phytol. 108, 451-459.

Kayser A, Schröder T J, Grünwald A and Schulin R 2001 Solubilization and plant uptake of zinc and cadmium from soils treated with elemental sulphur. Int. J. Phytorem. 3, 381-400.

Kayser A, Wenger K, Keller A, Attinger W, Felix H R, Gupta S K and Schulin R 2000 Enhancement of phytoextraction of $\mathrm{Zn}, \mathrm{Cd}$, and $\mathrm{Cu}$ from calcareous soil: the use of NTA and sulfur amendments. Environ. Sci. Technol. 34, 1778-1783.

Keller C, Hammer D, Kayser A, Richner W, Brodbeck M and Sennhauser M 2003 Root development and heavy metal phytoextraction efficiency: comparison of different plant species in the field. Plant Soil 249, 67-81.

Lapeyrie F, Chilvers G A and Bhem C A 1987 Oxalic acid synthesis by the mycorrhizal fungus Paxillus involutus (Batsch. Ex Fr.) Fr. New. Phytol. 106, 139-146.

Lapeyrie F, Ranger J and Vairelles D 1991 Phosphate-solubilizing activity of ectomycorrhizal fungi in vitro. Can. J. Bot 69, 342-346.

Leyval C, Surtiningsih T and Berthelin J 1993 Mobilization of Cd from rock phosphates by rhizospheric microorganisms. Phosphorus Sulfur 77, 133-136.

Leyval C, Turnau K and Haselwandter K 1997 Effect of heavy metal pollution on mycorrhizal colonization and function: physiological, ecological and applied aspects. Mycorrhiza 7, 139-153.

Loree M A J, Lumme I, Niemi M and Tormala T 1989 Inoculation of Salix spp. with ectomycorrhizal fungi on mined boreal peatland. Plant Soil 116, 229-238.

Marx D H and Bryan W C 1975 Growth and ectomycorrhizal development of loblolly pine seedlings in fumigated soil infested with the fungal symbiont Pisolithus tinctorius. For. Sci. 21, 245-254.

McGrath S P, Zhao F J and Lombi E 2001 Plant and rhizosphere processes involved in phytoremediation of metal-contaminated soils. Plant Soil 232, 207-214.

McIntyre T 2003 Phytoremediation of heavy metals from soils. Adv. Biochem. Engin/Biotechnol. 78, 97-123.

Meers E, Hopgood M, Lesage E, Vervaeke P, Tack F M G and Verloo M G 2004 Enhanced phytoextraction: in search of EDTA alternatives. Int. J. Phytorem. 6, 95-109.

Prasad M N V and de Oliveira Freitas H M 2003 Metal hyperaccumulation in plants - biodiversity prospecting for phytoremediation technology. Ectr. J. Biotechnol. 6, 285-321.

Püttsepp Ü, Rosling A and Taylor A F S 2004 Ectomycorrhizal fungal communities associated with Salix viminalis $\mathrm{L}$. and $S$. dasyclados Wimm. clones in a short-rotation forestry plantation. Forest Ecol. Manag. 196, 413-424.

Robinson B H, Mills T M, Petit D, Fung L E, Green S R and Clothier B E 2000 Natural and induced cadmium-accumulation in poplar and willow: implications for phytoremediation. Plant Soil 227, 301-306.

Rockwood D L, Naidu C V, Carter D R, Rahmani M, Spriggs T A, Lin C, Alker G R, Isebrands J G and Segrest S A 2004 Short-rotation wood crops and phytoremediation: opportunities for agroforestry? Agroforest. Syst. 61, 51-63.

Salzer P and Hager A 1993 Effects of auxins and ectomycorrhizal elicitors on wall-bound proteins and enzymes of spruce cells. Trees 8, 49-55.

Saxena P K, KrishnaRaj S, Dan T, Perras M R and Vettakkorumakankav N N 1999 Phytoremediation of heavy metal contaminated and polluted soils. In Heavy Metal Stress in Plants. Eds. M N V Prasad and J Hagemeyer pp. 305-329. Springer, Berlin.

Schulin R, Zeyer J, Gupta S and Gälli R 1997 Problem substanzen im Boden und Sanfte Bodensanierung. TerraTech 2+3, 4-5.

Smith S E and Read D J 1997 Mycorrhizal Symbiosis. Academic Press.

Tam P C F 1995 Heavy metal tolerance by ectomycorrhizal fungi and metal amelioration by Pisolithus tinctorius. Mycorrhiza 5, 181-187.

Turnau K, Dexheimer J and Botton B 1995 Heavy metal sequestration and filtering effect in selected mycorrhizas from calamine dumps - EDAX microanalysis. In Proceedings of 10th international conference on heavy metals in the environment, Hamburg, 1995. pp. 317-320.

Turner A P 1994 The responses of plants to heavy metals. In Toxic Metals in Soil-Plant Systems. Ed. S M Ross. pp. 152-187. John Wiley \& Sons Ltd, Chichester, UK.

Vogel H, Desaules A and Häni H 1989 Schwermetallgehalte in den Böden der Schweiz. National Research Programme 22. Bern-Liebefeld, Switzerland 118 pp.

Wallenda T and Kottke I 1998 Nitrogen deposition and ectomycorrhizas. New Phytol. 139, 169-187.

Wenger K, Kayser A, Gupta S K, Furrer G and Schulin R 2002 comparison of NTA and elemental sulfur as potential soil amendments in phytoremediation. Soil Sediment Contam. $11,655-672$.

Wilkinson D M and Dickinson N M 1995 Metal resistance in trees: The role of mycorrhizae. OIKOS 72, 2.

Section editor: J.W.G. Cairney 